\title{
Potential of ethyl acetate fractions of Stryphnodendron adstringens shells and fruit extracts of Caesalpinia ferrea to control bacterial leaf speck and on the potentiation of defense enzymes in tomato
}

\author{
Gilcianny Pignata Cavalcante ${ }^{1}$, Renata Sousa Resende', João Paulo Viana Leite ${ }^{2}$, José Rogério de \\ Oliveira $^{1}$ \& Fabrício de Ávila Rodrigues ${ }^{1}$
}

${ }^{1}$ Departamento de Fitopatologia, Universidade Federal de Viçosa, 36570-900, Viçosa, MG, Brazil; ${ }^{2}$ Departamento Bioquímica e Biologia Molecular, Universidade Federal de Viçosa, 36570-900, Viçosa, MG, Brazil

Author for correspondence: Fabrício A. Rodrigues, e-mail: fabricio@ufv.br

\begin{abstract}
Considering the importance of bacterial leaf speck (Pseudomonas syringae pv. tomato) in reducing tomato yield and difficulties in disease control, this study investigated the effects of fractions of shells extract of Stryphnodendron adstringens ( Sa) and fruit extract of Caesalpinia ferrea $(C f)$ compared to Acibenzolar-S-Methyl (ASM) on reducing bacterial leaf speck symptoms and on the potentiation of the activities of defense enzymes. The number of lesions per plant (NLP) was significantly lower in plants treated with the ethyl acetate fraction (EAF) of $S$. adstringens $(S a)$ and ASM compared to other treatments (EAF of $C f, n$-butanol fractions of $S a$ and $C f$, aqueous fractions of $S a$ and $C f$ and sterile distilled water). The bacteria were inhibited by the EAF of $S a$ and EAF of $C f$ and $n$-butanol fractions of $S a$ and $C f$ according to the bioautography assay. Saponins and tannins were the two major compounds found in these fractions based on the phytochemical analysis. Peroxidase (POX), polyphenoloxidase (PPO), $\beta$-1,3-glucanase (GLU) and phenylalanine ammonia-lyase (PAL) activities were determined on the leaves of plants treated with EAF Sa, ASM and sterile distilled water. Both POX and PAL activities were higher at 3 and 6 days after inoculation (dai), while the PPO and GLU activities were higher from 9 to 12 dai. It is suggested that saponins increased tomato resistance to $P$. s. pv. tomato because no antimicrobial activity against the bacteria was observed. In conclusion, the EAF $\mathrm{Sa}$ was very efficient in reducing bacterial leaf speck symptoms in conditions where the POX, PPO, PAL and GLU activities played a pivotal role in increasing tomato resistance to the disease.
\end{abstract}

Key words: Pseudomonas syringae pv. tomato, Solanum lycopersicum, induced host resistance, plant extracts.

\section{INTRODUCTION}

Tomato (Solanum lycopersicum L.) is one of the most consumed vegetables worldwide (Minami \& Haag, 1989), and the occurrence of diseases can dramatically reduce its yield. Among the diseases that affect tomato plants, bacterial leaf speck, which is caused by Pseudomonas syringae pv. tomato (Pst) (Okabe, 1933; Young et al., 1978), is the most important (Silva \& Lopes, 1995). Bacterial leaf speck can cause yield losses of up to $30 \%$ when tomato plants are grown in regions with high relative humidity and temperatures ranging from $20^{\circ} \mathrm{C}$ to $25^{\circ} \mathrm{C}$ (Silva \& Lopes, 1995). Products containing copper and the inducer of resistance Acibenzolar-SMethyl, in addition to the use of cultivars containing the resistant Pto gene, such as the cultivar BRS Tospodoro, are the current disease control methods recommended to growers (Lopes \& Santos, 1994; Giordano et al., 2010). The tomato crop is one of the most dependent on the application of pesticides, which results in an increase in production costs and the selection of pathogen-resistant populations in addition to being toxic to growers and the environment (Mariconi, 1981).

In Brazil, there is considerable diversity among plant species capable of synthesizing a wide range of products that have antimicrobial activity against various microorganisms (Almeida, 1993). The compounds originating from the plants' secondary metabolism have no direct role in their growth but promote a better fitness in the environment (Taiz $\&$ Zeigher, 2004). Among the secondary metabolites, some compounds that exhibit antimicrobial activity are of special importance, such as essential oils, saponins, flavonoids, coumarins, phytoalexins, tannins and alkaloids (Taiz \& Zeigher, 2004; Gurjar et al., 2012). The plant extracts that contain many of these metabolites have been investigated for their increased resistance against pathogens infection, such as the zimmu extract (Allium sativum L. $\mathrm{x}$ Allium cepa $\mathrm{L}$.) in the control of Xanthomonas campestris pv. malvacearum on cotton (Satya et al., 2007) and Lasiodiplodia theobromae and Colletotrichum musae on banana (Sangeetha et al., 2013 ). Extracts of Datura metel increased rice resistance against Rhizoctonia solani and X. oryzae pv. oryzae (Kagale 
et al., 2004), and the extract of Hedera helix reduced the symptoms of Erwinia amylovora on apple (Baysal \& Zeller, 2004).

Induced resistance is a phenomenon that allows plants to enhance their level of basal resistance against pathogens attacks (Weller et al., 2012). According to Glazebrook (2005), Acibenzolar-S-Methyl (ASM), an analog of salicylic acid, is known to play a pivotal role in the signaling pathway that results in systemic acquired resistance (SAR). Diseases caused by $X$. vesicatoria, $P$. syringae pv. tomato, Clavibacter michiganensis subsp. michiganensis and Ralstonia solanacearum in tomato (Louws et al., 2001; Soylu et al., 2003, Ji et al., 2005; Cavalcanti et al., 2006) and $X$. axonopodis pv. passiflorae in passion fruit (Boro et al., 2011) showed decreased severities when the plants were sprayed with ASM. One of the plant defense mechanism against pathogens related to SAR is the activation of genes coding for chitinases, $\beta$-1,3-glucanases, phenylalanine ammonia-lyases, polyphenoloxidases and peroxidases (Van Loon, 1997).

The effects of fractions obtained from fruit extracts of Caesalpinia ferrea and shells of Stryphnodendron adstringens compared to the known inducer of resistance ASM were investigated as an alternative in reducing bacterial leaf speck symptoms and potentiating the activities of enzymes in tomato leaves.

\section{MATERIALS AND METHODS}

\section{Plant materials}

Stem bark samples were collected from "Barbatimão" (Stryphnodendron adstringens) tree trunks, and fruits were obtained from "Jucá" (Caesalpinia ferrea) trees in Boa Vista City, Roraima State, Brazil. Specimens obtained from these two plant species were deposited in the herbarium of the Universidade Federal de Roraima (Boa Vista, RO, Brazil) on January 2013 with the codes 3446 and 3445 for S. adstringens and C. ferrea, respectively. After collection, the stem bark and fruits were dried at room temperature $\left(25^{\circ} \mathrm{C}\right)$ in a ventilated room for one week and stabilized in a circulating air oven at $40^{\circ} \mathrm{C}$ for 5 days. Next, the dried material was ground using a Thomas-Wiley mill and stored in glass vials protected from moisture and light using aluminum foil.

\section{Extraction and fractionation of $S$. adstringens and $C$. ferrea components}

Aqueous extracts of the stem bark and fruits were prepared by infusion at a ratio of 1:20 w/v (plant material: distilled water), boiled in water for $30 \mathrm{~min}$ with constant agitation, and then filtered through cotton. The aqueous extracts obtained were frozen at $-80^{\circ} \mathrm{C}$; the extracts were then freeze-dried and stored in a dry location in the dark. Subsequently, a total of $10 \mathrm{~g}$ of each lyophilized material was resuspended in water $(200 \mathrm{~mL})$, because the fractions were derived from aqueous extract. Afterward, the fractions were subjected to liquid-liquid serial and exhaustive partitioning in separator funnels with solvents of increasing polarity, resulting in the following fractions: ethyl acetate fraction of $S$. adstringens (EAF $S a$ ), ethyl acetate fraction of $C$. ferrea (EAF $C f$ ), $n$-butanol fraction of $S$. adstringens (BF $S a$ ), $n$-butanol fraction of $C$. ferrea (BF $C f$ ), aqueous fraction of $S$. adstringens (AF $S a$ ) and aqueous fraction of $C$. ferrea (AF $C f$ ). The ethyl acetate and $n$-butanol fractions were concentrated using a rotary evaporator at $50^{\circ} \mathrm{C}$ and $85^{\circ} \mathrm{C}$, respectively. The vials were placed in a desiccator until the solvent was completely evaporated. The aqueous fractions were freeze-dried to remove the solvent.

\section{Bioauthography}

The bioautography was performed by Thin Layer Chromatography (TLC) employing TLC plates (SIL ALIGRAM g/UV 254, Merck) according to Wagner \& Bladt (1996). A total of $10 \mathrm{ml}$ of each fraction, re-suspended in methanol $(5 \mathrm{mg} / 100 \mu \mathrm{l})$ and then eluted with mobile phase $n$-butanol/acetic glacial acid/water (45:10:35), was pipetted at each TLC plate. After elution, chromatographic plates were dried in a laminar flow in environment temperature for 5 days for complete removal of the solvent. Afterwards, they were sprayed with bacterial suspension. The bacterium was grown in liquid medium 523 (saccharose $10 \mathrm{~g}$, casein acid hydrolysate $8 \mathrm{~g}$, yeast extract $4 \mathrm{~g}, \mathrm{~K}_{2} \mathrm{HPO}_{4} 2 \mathrm{~g}, \mathrm{MgSO}_{4} .7 \mathrm{H}_{2} \mathrm{O}$ $0,3 \mathrm{~g}$, agar $15 \mathrm{~g}$, distilled water $1000 \mathrm{~mL}$ ) (Kado \& Heskett, 1970) for $48 \mathrm{~h}$. Subsequently, $100 \mu \mathrm{L}$ of the bacterial suspension at $1.0 \times 10^{8} \mathrm{CFU} / \mathrm{mL}$ were transferred to $20 \mathrm{ml}$ of the medium $523 \mathrm{semi}$-solid at $50^{\circ} \mathrm{C}$ which was sprayed to completely cover the plates. Plates coated with layer of bacterial suspension were maintained at $28^{\circ} \mathrm{C}$ for 48 hours and then sprayed with triphenyltetrazolium chloride (TTC) a concentration of $20 \mathrm{mg} / \mathrm{ml}$. The assay was performed in triplicate and the halos observed in the bioautograms were measured.

\section{Phytochemical evaluation}

Analysis of the chemical components was performed for different groups of secondary metabolites, such as anthraquinones, coumarins, flavonoids, cardiotonic heterosides, saponins, alkaloids and tannin using TLC according to Wagner \& Bladt (1996). To characterize the chromatograms, specific reagents for each group of secondary metabolites were used as follow: anthraquinones (1,8 diidroxiantraquinona), coumarins (venalot), flavonoids (quercetina), cardiotonic (digitoxicina), saponins (18- $\beta$ glicirretínico), alkaloids (quinina) and tannins (pyrogallic acid). The eluent used for the separation of the compounds was a solution consisting of glacial acetic acid, $n$-butanol and water in the proportion of 45:10:35 ( $/ / \mathrm{v} / \mathrm{v})$. The fractions were solubilized in methanol $(5 \mathrm{mg} / 100 \mu \mathrm{L})$ and deposited onto the plates using capillary glass. In some instances, they were detected under ultraviolet light $(\lambda=$ from 254 to $365 \mathrm{~nm}$ ) in a darkroom. The results obtained 
using chromatography were compared with the respective standards.

\section{Plant growth}

Tomato seeds from the cultivar "Santa Clara" were sowed in plastic trays containing a substrate (Plantmax). Twenty-one days after sowing, the plants were transplanted into plastic pots containing $2 \mathrm{~kg}$ of substrate. Fifteen days after transplantation, the plants received $40 \mathrm{~mL}$ of a nutrient solution containing (in $\mathrm{mg} / \mathrm{L}$ ) $0.192 \mathrm{KCl}, 0.104 \mathrm{~K}_{2} \mathrm{SO}_{4}$, $0.150 \mathrm{MgSO}_{4} .7 \mathrm{H}_{2} \mathrm{O}, 0.061$ urea, $0.1 \mathrm{NH}_{4} \mathrm{NO}_{3}, 0.0003$ $\left(\mathrm{NH}_{4}\right)_{6} \mathrm{Mo}_{7} \mathrm{O}_{24} \cdot 4 \mathrm{H}_{2} \mathrm{O}, 0.002 \mathrm{H}_{3} \mathrm{BO}_{3}, 0.007 \mathrm{ZnSO}_{4}, 0.002$ $\mathrm{CuSO}_{4} .5 \mathrm{H}_{2} \mathrm{O}, 0.004 \mathrm{MnCl}_{2} .4 \mathrm{H}_{2} \mathrm{O}, 0.004 \mathrm{FeSO}_{4} .7 \mathrm{H}_{2} \mathrm{O}$ and 0.006 disodium EDTA. The plants were maintained in a greenhouse (temperature of $25 \pm 2^{\circ} \mathrm{C}$, humidity relative of $65 \pm 5 \%$ and 12 hours light/12 hours dark) and irrigated as needed.

\section{Inoculum of $\boldsymbol{P s t}$ and bacterial suspension preparation}

The isolate of Pst was obtained from tomato plants with typical symptoms of bacterial leaf speck in Coimbra, Minas Gerais state, Brazil. The isolate (UFV-DFP 06) was preserved in $30 \%$ glycerol at $-80^{\circ} \mathrm{C}$ (Gonçalves et al., 2007), and its identity was confirmed using a pathogenicity test on tomato plants, LOPAT tests (Schaad, 1988) and sequencing analysis of the mitochondrial $16 \mathrm{~S}$ ribosomal rRNA gene fragment. For use in the experiments, the Pst isolate was grown in 523 medium (Kado \& Heskett, 1970) using the stretch mark method for $24 \mathrm{~h}$ at $28^{\circ} \mathrm{C}$. Subsequently, the bacterial suspension was prepared in a $0.85 \%$ saline solution, and the bacterial concentration was adjusted to absorbance $_{540}=0.20$, which was approximately $1.0 \times 10^{8}$ $\mathrm{CFU} / \mathrm{mL}$.

\section{Evaluation of the effect of fractions of the extracts against bacterial speck}

The following treatments were used in this experiment: $\mathrm{EAF} C f$, BF $C f$, AF $C f$, EAF $S a$, BF $S a, \mathrm{AF}$ $\mathrm{Sa}$, sterile distilled water (SDW) and ASM. The plants were sprayed with a solution of ASM at a concentration of 0.05 $\mathrm{g} / \mathrm{L}(25 \mathrm{~mL}$ per plant). The extract fractions were diluted with water to a final concentration of $0.06 \mathrm{~g} / \mathrm{L}$, and 10 $\mathrm{mL}$ of each fraction was added to each plastic pot three days before inoculation with Pst. Tomato plants were inoculated at 15 days after transplant with a suspension of Pst at a concentration of $1.0 \times 10^{8} \mathrm{CFU} \mathrm{mL}^{-1}$ using a VL Airbrush atomizer (Paasche Airbrush Co.). Plants were maintained in a mist chamber for $24 \mathrm{~h}$ prior to inoculation and for an additional $24 \mathrm{~h}$ thereafter. After inoculation, the plants were placed in a growth chamber (temperature of $25 \pm 2^{\circ} \mathrm{C}$, relative humidity of $80 \pm 5 \%$ and photoperiod of $12 \mathrm{~h}$ light) for $24 \mathrm{~h}$. The number of lesions per plant (NLP) was evaluated at seven days after inoculation by counting the number of spots on all the leaves of each plant per replication of each treatment according to Schneider \& Grogan (1977).
Determination of peroxidase (POX, EC1.11.1.7), polyphenoloxidase (PPO, EC 1.10.3.1), $\beta$-1,3-glucanase (GLU, EC 3.2.1.39) and phenylalanine ammonia-lyase (PAL, EC 4.3.1.5) activities

In a separated experiment, leaf samples of plants from each replication and treatment were collected at 3,6, 9 and 12 dai. Leaf samples from non-inoculated plants were collected at the same evaluation times. After sampling, leaf samples were stored individually in aluminum foil, rapidly frozen in liquid nitrogen and then stored in ultrafreezer at $-80^{\circ} \mathrm{C}$ for further analysis.

To obtain the extracts used to determine the activities of POX, PPO, GLU and PAL, $0.3 \mathrm{~g}$ of leaf tissues was macerated with liquid nitrogen in a mortar with the addition of polyvinylpyrrolidone (PVP) $1 \%(\mathrm{w} / \mathrm{v})$ to obtain a fine powder. The powder was homogenized in $2 \mathrm{~mL}$ of 50 $\mathrm{mM}$ sodium phosphate buffer ( $\mathrm{pH}$ 6.5) containing $1 \mathrm{mM}$ phenylmethylsulfonicfluoride (PMSF). The homogenized material was centrifuged at $20,000 \times g$ for $25 \mathrm{~min}$ at $4{ }^{\circ} \mathrm{C}$ and the supernatant was used to determine the enzymes activities. The POX and PPO activities were determined by the oxidation of pyrogallol according to the method of Kar \& Mishra (1976). For POX activity, a mixture of $300 \mu \mathrm{L}$ of distilled water, $250 \mu \mathrm{L}$ of $100 \mathrm{mM}$ potassium phosphate buffer (pH 6.8), $200 \mu \mathrm{L}$ of $100 \mathrm{mM}$ pyrogallol and $200 \mu \mathrm{L}$ of $100 \mathrm{mM}$ hydrogen peroxide was added to $50 \mu \mathrm{L}$ of the extract. For PPO activity, the mixture was composed of $350 \mu \mathrm{L}$ of distilled water, $350 \mu \mathrm{L}$ of $100 \mathrm{mM}$ potassium phosphate buffer ( $\mathrm{pH} 6.8)$ and $200 \mu \mathrm{L}$ of 100 $\mathrm{mM}$ pyrogallol, which was added to $100 \mu \mathrm{L}$ of the extract. The absorbance was measured in a spectrophotometer (Evolution 60, Thermo Scientific) at $420 \mathrm{~nm}$ every 10 seconds for $1 \mathrm{~min}$ after addition of the extract to the mixture in a total of five readings. The molar extinction coefficient of $2.47 \mathrm{mM}^{-1} \mathrm{~cm}^{-1}$ was used to calculate POX and PPO activities (Chance \& Maehley, 1955), which were expressed in $\mathrm{mM}$ and $\mu \mathrm{M}$ of purpurogallin produced $\mathrm{min}^{-1}$ $\mathrm{mg}^{-1}$ of protein, respectively. Throughout the process, the microcentrifuge tubes were covered with aluminum foil to protect the mixture from oxidation by light. The GLU activity was determined as described by Lever (1972). The reaction was initiated by the addition of $20 \mu \mathrm{L}$ aliquots of the supernatant to a mixture of $230 \mu \mathrm{L}$ of $100 \mathrm{mM}$ sodium acetate buffer ( $\mathrm{pH} \mathrm{5.0)}$ and $250 \mu \mathrm{L}$ of the substrate laminarin (Sigma-Aldrich) in a concentration of $4 \mathrm{mg} / \mathrm{mL}$. The reaction mixture was incubated in a water bath for $30 \mathrm{~min}$ at $45^{\circ} \mathrm{C}$. After the incubation period, the amount of reducing sugars was determined by adding $500 \mu \mathrm{L}$ of dinitrosalicylic acid to the mixture and then incubating the resulting mixture in a water bath for $15 \mathrm{~min}$ at $100^{\circ} \mathrm{C}$. The reaction was interrupted by cooling the samples in an ice bath. In the control samples, the reaction mixture was the same, except that the dinitrosalicylic acid was add at the same time as the extract. The absorbance of the product released by GLU was measured at $540 \mathrm{~nm}$ and the activity of GLU was expressed in absorbance units $\mathrm{min}^{-1} \mathrm{mg}^{-1}$ of 
protein. PAL activity was determined by adding $100 \mu \mathrm{L}$ of the extract to a mixture containing $350 \mu \mathrm{L}$ of 25 $\mathrm{mM}$ Tris- $\mathrm{HCl}$ buffer $(\mathrm{pH} 8.8)$ and $550 \mu \mathrm{L}$ of $100 \mathrm{mM}$ $L$-phenylalanine. The reaction mixture was incubated in a water bath at $30^{\circ} \mathrm{C}$ for $4 \mathrm{~h}$. In the control samples, the $L$-phenylalanine was replaced with $1 \mathrm{~mL}$ of Tris- $\mathrm{HCl}$ buffer. The reaction was finalized by adding $60 \mu \mathrm{L}$ of $6 \mathrm{~N} \mathrm{HCl}$. The absorbance of the trans-cinnamic acid derivatives was measured in a spectrophotometer at 290 $\mathrm{nm}$ and the molar extinction coefficient of $10^{4} \mathrm{mM}^{-1} \mathrm{~cm}^{-1}$ (Zucker, 1965) was used to calculate PAL activity, which was expressed in $\mathrm{nM} \mathrm{min}{ }^{-1} \mathrm{mg}^{-1}$ of protein.

The protein concentration in each sample was determined according to the method of Bradford (1976).

\section{Experimental design and statistical analysis}

One experiment was performed in a completely randomized design with eight treatments and three replications to evaluate the NLP. This experiment was repeated once. The data were subjected to analysis of variance (ANOVA), and the treatment means were compared using Duncan's test at a probability of 5\% and was calculated the standard deviation of the mean. Another experiment was performed in a completely randomized design with six treatments and four replications to obtain samples to determine the enzymes activities. This experiment was repeated once. The data were analyzed using ANOVA, and the treatment means were compared using confidence intervals at a probability of 5\%. Statistical analyses were performed using SAS software (version 9.1, SAS Institute, Inc.).

\section{RESULTS}

\section{Plant extracts activity}

The bioautography was carried out in order to find out which compounds were responsible for the antimicrobial activity in the fractions studied. The $P$. $s$. pv. tomato growth was inhibited by fractions of $C$. ferrea and $S$. adstringens both in ethyl acetate and $n$-butanol. There was no significant differente between the zones of inhibition promoted by the two fractions. The aqueous fractions showed no activity against the bacteria. The phytochemical screening of the fractions of C. ferrea and S. adstringens in ethyl acetate and $n$-butanol revealed the presence of tannins and saponins, but the antimicrobial activity may have conferred by the former as evidenced by the formation of an inhibition zone in the bioauthography assay.

\section{Number of bacterial leaf speck lesions}

For Exp 1, NLP of bacterial leaf speck was reduced by $97 \%, 82 \%$ and $80 \%$ for the ASM, EAF $S a$ and BF $S a$ treatments, respectively, compared to the control treatment (Table 1). For Exp 2, NLP was reduced by $71 \%, 51 \%$ and $47 \%$ for the EAF $S a$, ASM and BF $C f$ treatments, respectively, compared to the control treatment (Table 2).
TABLE 1 - NLP (number of lesions per plant) from the following treatments: ethyl acetate fraction of $S$. adstringens (EAF $S a$ ), ethyl acetate of $C$. ferrea (EAF Cf), $n$-butanol fraction of $S$. adstringens (BF $S a), n$ - butanol fraction of $C$. ferrea (BF $C f$ ), aqueous fraction of $S$. adstringens (AF $S a$ ), aqueous fraction of $C$. ferrea (AF $C f)$, sterile distilled water (SDW) and Acibenzolar-S-Methyl (ASM) in Experiment 1. Means followed by the same letter are not significantly different $(P \leq 0.05)$ by Duncan's test. SDM = standard deviation of means.

\begin{tabular}{lcc}
\hline \hline Treatments & NLP & SDM \\
\hline SDW & $998.3 \mathrm{a}$ & 146.1 \\
BF $C f$ & $646.0 \mathrm{~b}$ & 30.0 \\
EAF $C f$ & $558.0 \mathrm{~b}$ & 5.2 \\
AF $C f$ & $548.0 \mathrm{~b}$ & 124.9 \\
AF $S a$ & $485.3 \mathrm{bc}$ & 33.5 \\
BF $S a$ & $198.0 \mathrm{~cd}$ & 56.6 \\
EAF $S a$ & $183.0 \mathrm{~cd}$ & 17.3 \\
ASM & $35.3 \mathrm{~d}$ & 8.7 \\
\hline
\end{tabular}

TABLE 2 - NLP (number of lesions per plant) from the following treatments: ethyl acetate fraction of $S$. adstringens (EAF $S a$ ), ethyl acetate of $C$. ferrea (EAF $C f), n$-butanol fraction of $S$. adstringens (BF $S a$ ), $n$-butanol fraction of $C$. ferrea (BF $C f$ ), aqueous fraction of $S$. adstringens (AF $S a$ ), aqueous fraction of $C$. ferrea (AF $C f$ ), sterile distilled water (SDW) and Acibenzolar-S-Methyl (ASM) on in Experiment 2. Means followed by the same letter are not significantly different $(P \leq 0.05)$ by Duncan's test. SDM $=$ standard deviation of means.

\begin{tabular}{lcc}
\hline \hline Treatments & NLP & SDM \\
\hline $\mathrm{AF} S a$ & $2154.3 \mathrm{a}$ & 393.5 \\
$\mathrm{SDW}$ & $1760.0 \mathrm{a}$ & 322.2 \\
$\mathrm{EAF} C f$ & $1225.0 \mathrm{ab}$ & 30.6 \\
$\mathrm{AF} C f$ & $1194.0 \mathrm{ab}$ & 10.9 \\
$\mathrm{BF} S a$ & $1182.3 \mathrm{ab}$ & 81.7 \\
$\mathrm{BF} C f$ & $684.0 \mathrm{~b}$ & 478.8 \\
$\mathrm{ASM}$ & $634.0 \mathrm{~b}$ & 32.8 \\
$\mathrm{EAF} \mathrm{Sa}$ & $373.0 \mathrm{~b}$ & 13.3 \\
\hline
\end{tabular}

\section{Activities of defense enzymes}

The treatmentEAF $S a$, thatresulted in betterprotection against bacterial speck, was utilized for the experiment aiming to determine the activity of defense enzymes. For the non-inoculated plants, there was a significant difference between the ASM and control treatments at 3 dai and between the control treatment compared to the EAF Sa and ASM treatments at 12 dai (Figure 1A). In addition, POX activity was significantly greater for the inoculated plants treated with EAF $S a$ and ASM at 6 dai. At 9 and 12 dai, POX activity was significantly higher in plants sprayed with ASM compared to the EAF $S a$ and control treatments (Figure 1B). For the non-inoculated plants, there was no significant difference among the treatments for PPO activity (Figure 2A). PPO activity for the inoculated plants sprayed with ASM was significantly higher at 3 and 6 dai compared to the EAF $S a$ and control treatments. For PPO activity at 9 and 12 dai, there was a significant difference for the ASM 
Potential of ethyl acetate fractions of Stryphnodendron adstringens shells and fruit extracts...
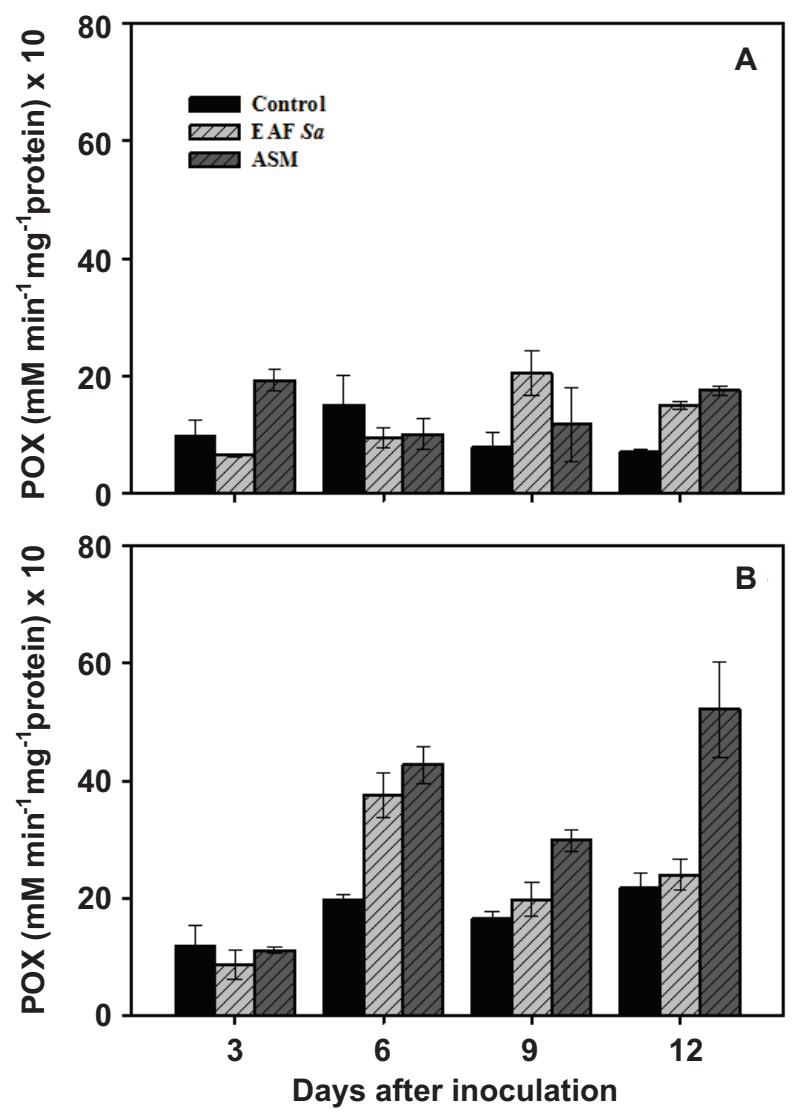

FIGURE 1 - Activity of peroxidases (POX) on the leaves of tomato plants non-inoculated (A) or inoculated (B) with Pseudomonas syringae pv. tomato and treated with the ethyl acetate fraction of $S$. adstringens (EAF $S a$ ), sterile distilled water (control) and Acibenzolar-S-Methyl (ASM). The bars represent the confidence intervals at a probability of $5 \%$.

and EAF $S a$ treatments compared to the control treatment (Figure 2B). The GLU activity for non-inoculated plants was significantly higher at 9 and 12 days for the plants treated with EAF $S a$ and ASM compared to the control treatment (Figure 3A). The GLU activity was significantly higher for the inoculated plants and for plants sprayed with ASM at 3 and 6 dai compared to the EAF $S a$ and control treatments. At 9 dai, the GLU activity significantly increased in the inoculated plants treated with ASM or EAF $\mathrm{Sa}$, but there was no significant difference between these two treatments. Moreover, GLU activity was higher at 12 dai for the inoculated plants treated with ASM and EAF $\mathrm{Sa}$ with a significant difference between these treatments as well as a significant difference compared to the control treatment (Figure 3B). For the non-inoculated plants treated with ASM or EAF $S a$, PAL activity was significantly higher at 3 and 6 days compared to the control treatment. At 9 and 12 days, there was no significant difference between the ASM and EAF $S a$ treatments for GLU activity (Figure 4A). Furthermore, PAL activity in the inoculated plants treated with ASM and EAF $S a$ was significantly higher compared
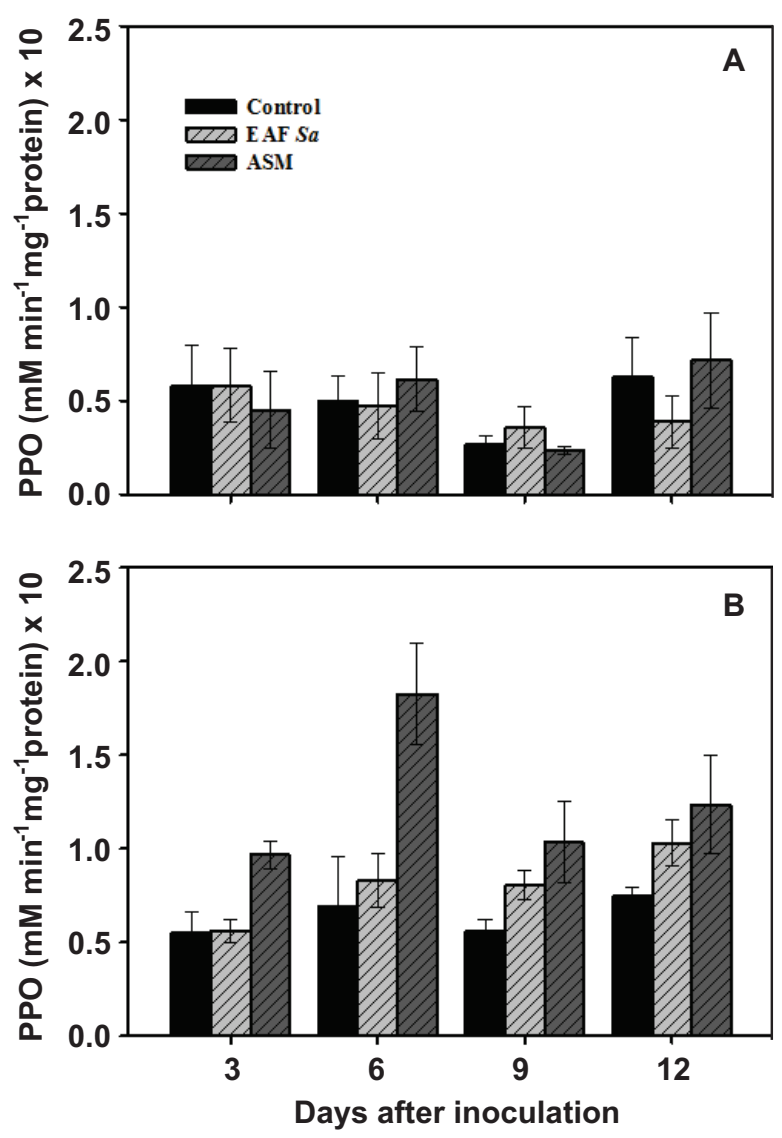

FIGURE 2 - Activity of polyphenoloxidases (PPO) on the leaves of tomato plants non-inoculated (A) or inoculated (B) with Pseudomonas syringae pv. tomato and treated with the ethyl acetate fraction of $S$. adstringens (EAF $S a$ ), sterile distilled water (SDW) and Acibenzolar-S-Methyl (ASM). The bars represent the confidence intervals at a probability of $5 \%$.

to the control treatment. At 3 dai, the PAL activity for plants treated with EAF $S a$ was significantly higher compared to the other treatments. At 6 dai, the PAL activity was significantly higher for the ASM and EAF $S a$ treatments compared to the control treatment, and at 9 dai, PAL activity was significantly higher for plants sprayed with ASM compared to the other treatments (Figure 4B).

\section{DISCUSSION}

To the best of our knowledge, this study is the first to demonstrate the potential of the extracts obtained from $S$. adstringens and C. ferrea in reducing bacterial leaf speck symptoms in tomato plants with a consequent increase in the activities of defense enzymes. The ethyl acetate fraction obtained from the fruits of $S$. adstringens contains substances that function as triggers of defense responses in tomato plants to protect against $P s t$ infection. The phytochemical evaluation performed on the fractions in ethyl acetate indicated the presence of tannins and saponins. Probably the tannins were the compounds responsible for the 

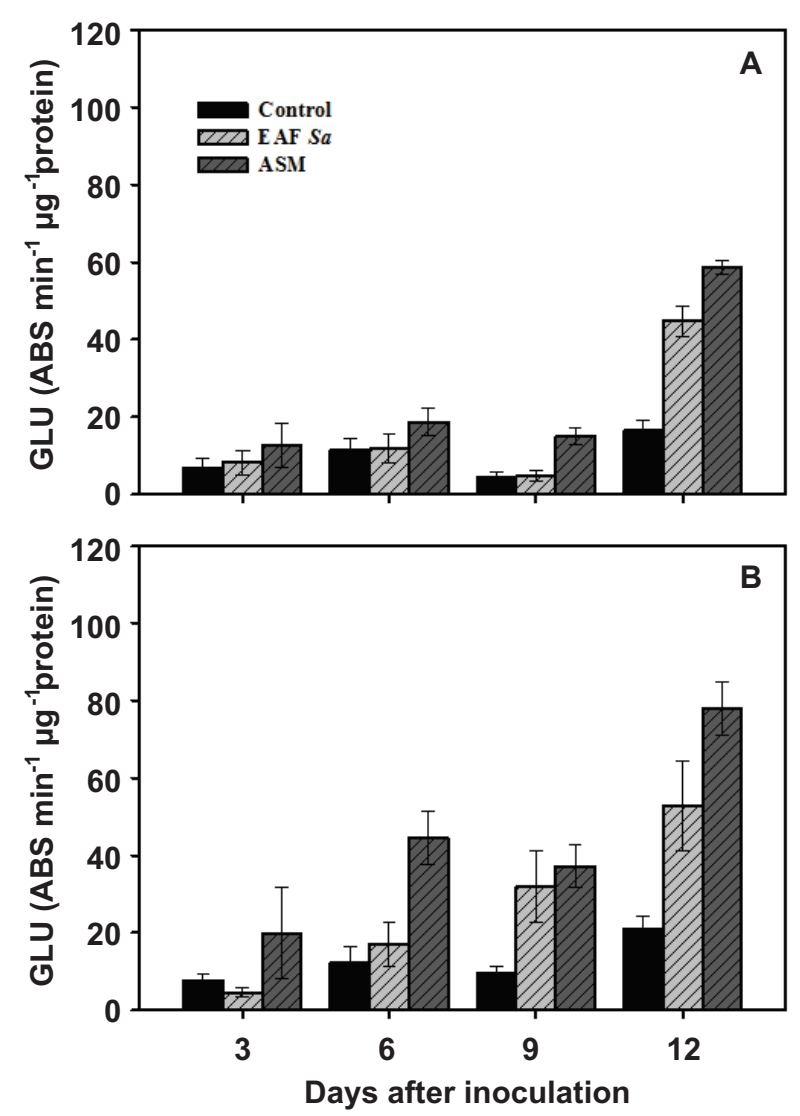

FIGURE 3 - Activity of $\beta$-1,3-glucanases (GLU) on the leaves of tomato plants non-inoculated (A) or inoculated (B) with Pseudomonas syringae pv. tomato and treated with the ethyl acetate fraction of $S$. adstringens (EAF $S a$ ), sterile distilled water (control) and Acibenzolar-S-Methyl (ASM). The bars represent the confidence intervals at a probability of $5 \%$.

antimicrobial activity against $P$. s. pv. tomato determined in the bioauthography assay. Tannins act by inhibiting bacterial and fungal enzymes and/or by complexing with enzyme substrates. In addition, tannins act on the cell membranes of microorganisms, thereby altering their metabolism via the inhibition of oxidative phosphorylation or by complexing metal ions, which reduces the availability of ions that are essential for microbial metabolism (Scalbert, 1991). It has been reported that avenacine and saponins are important compounds for oats resistance against pathogens (Osbourn, 1996). It is known that saponins act in the disruption of fungal cell membranes releasing cyanide and inhibiting cellular respiration (Osbourn, 1996). It is suggested that saponins were the compounds responsible for the increase in resistance of the tomato plants against the infection by $P$. s. pv. tomato due to their no antimicrobial activity against the bacteria.

Natural compounds can enhance the capacity of plants to acquire resistance to a broad spectrum of pathogens (Dubey et al., 2011; Conrath et al., 2002; Pastor et al., 2012). This process called priming of defense can provide long-lasting resistance based in host defense reaction upon pathogen infection and can be maintained long after the initial stimulus (Conrath, 2011; Pastor et al., 2012). The host defense mechanisms against pathogens involve metabolic changes that are linked to changes in the concentration of proteins, which are also known as pathogenesis-related proteins (PR-proteins). In the present study, POX activity was high in plants treated with ASM and EAF $S a$, particularly in ASM-treated plants. Increased POX activity was also reported in tomato plants treated with ASM and citrus extract and in plants infected by Xanthomonas vesicatoria (Cavalcanti et al., 2006b). Furthermore, PPO and POX have phenolic compounds as substrates, and the products of their oxidation exhibit anti-microbial activity against pathogens (Mueller \& Beckman, 1974). POX is also involved in the biosynthesis of ethylene, indole-3-acetic acid, lignin and suberin (Quiroga et al., 2000). These enzymes are important in tissue lignification, which acts as a physical barrier that prevents or reduces pathogen colonization and also decreases the diffusion of lytic enzymes and non-selective toxins (Nicholson \& Hammerschimidt, 1992).
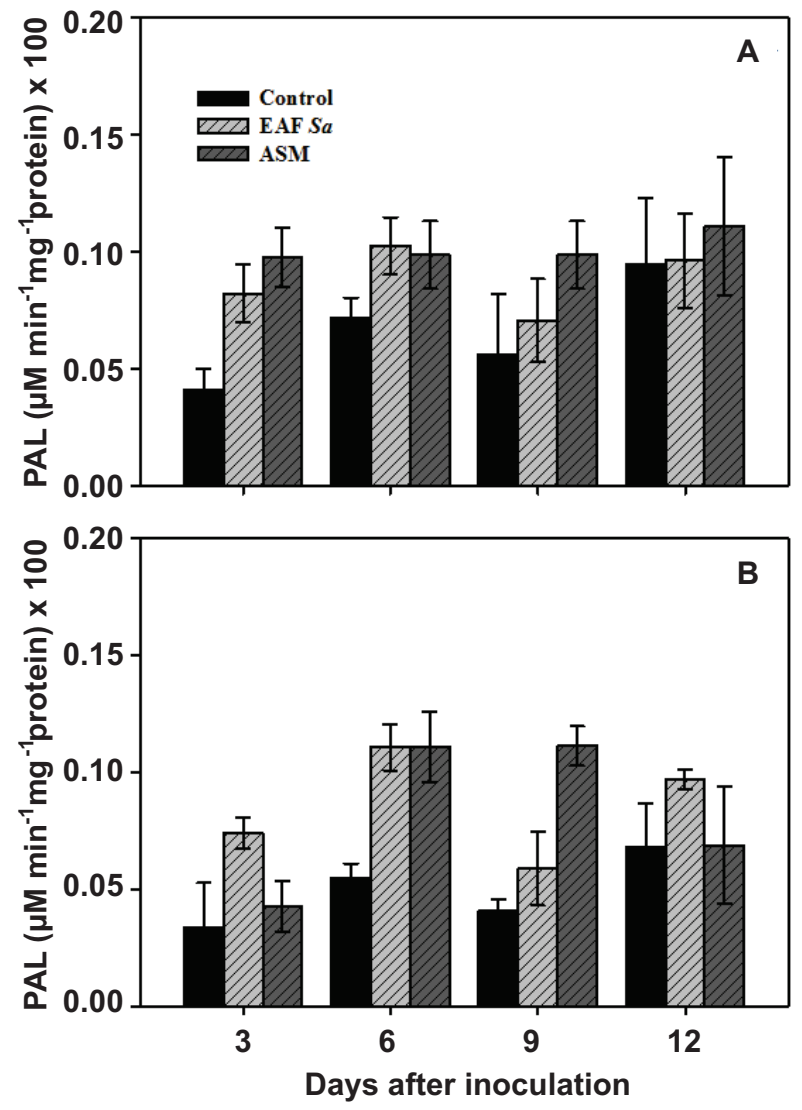

FIGURE 4 - Activity of phenylalanine ammonia-lyases (PAL) on the leaves of tomato plants non-inoculated (A) or inoculated (B) with Pseudomonas syringae pv. tomato and treated with the ethyl acetate fraction of $S$. adstringens (EAF $S a$ ), sterile distilled water (control) and Acibenzolar-S-Methyl (ASM). The bars represent the confidence intervals at a probability of $5 \%$. 
The PPO activity was higher in plants treated with ASM and EAF Sa. PPO is capable of catalyzing the oxidation of phenolic compounds to quinones, which are highly toxic compounds against pathogens (Li \& Steffens, 2002). Tomato plants overexpressing the PPO gene showed a greater capacity for oxidizing phenolic compounds and consequently a greater resistance against infection by Pst (Li \& Steffens, 2002). Sprays of the leaf Hedera helix extract and ASM increased the resistance of apple fruits to infection by Erwinia amylovora due to an increase in POX activity (Baysal \& Zeller, 2004).

Furthermore, GLU activity was high in plants sprayed with ASM prior to the appearance of bacterial leaf speck symptoms, which differed from plants treated with EAF $S a$, in which its activity was higher at advanced stages of bacterial infection. The faster and stronger GLU activity in plants sprayed with ASM indicated that the plants were in a primed state induced by ASM. The highest GLU activity was important for tomato resistance against infection by Erwinia amylovora and Xanthomonas campestris pv. vesicatoria (Brisset et al., 2000; Cavalcanti et al., 2006a). GLU is a lytic enzyme capable of degrading polysaccharides found in the cell walls of pathogens (Van Loon et al., 2006); however, its role in the resistance against bacterial pathogens remains unclear (Cavalcanti et al., 2006a).

PAL activity was also high in plants treated with EAF $S a$ before the appearance of bacterial leaf speck symptoms, and its activity was higher in plants treated with EAF $S a$ and ASM when the first bacterial leaf speck lesions were observed on the tomato leaves. Thus, it is proposed that there was an increase in the production of phenolic compounds in response to Pst infection during this period because PAL is responsible for the deamination of the amino acid $L$-phenylalanine, which forms trans-cinnamic acid and many other phenolic compounds (Hammerchmidt \& Nicholson, 1992; Assis et al., 2001). Cotton plants treated with the leaf extract of zimmu (Allium sativum L. $\times$ Allium cepa L.) showed higher activities of PAL, POX and PPO and high concentrations of phenolic compounds that contributed to an increase in resistance against $X$. campestris pv. malvacearum infection (Satya et al., 2007).

On the basis of these results, it can be concluded that the ethyl acetate fraction of $S$. adstringens was effective in reducing bacterial leaf speck symptoms on tomato leaves with the activities of the defense enzymes POX, PPO, PAL and GLU playing a pivotal role in the increase in host resistance.

\section{ACKNOWLEDGEMENTS}

Prof. F.A. Rodrigues thanks the Conselho Nacional de Desenvolvimento Científico e Tecnológico - CNPq for his research fellowship. This research was funded by grants received from Coordenação de Aperfeiçoamento de Pessoal de Nível Superior - CAPES, CNPq and Fundação de Amparo à Pesquisa do Estado de Minas Gerais - FAPEMIG.

\section{REFERENCES}

Almeida ER (1993) Plantas medicinais brasileiras: conhecimentos populares e científicos. São Paulo SP. Hemus.

Assis JS, Maldonado R, Muñoz T, Escribano MI, Merodio C (2001) Effect of high carbon dioxide concentration on PAL activity and phenolic contents in ripening cherimoya fruit. Postharvest Biology and Technology 23:33-39.

Baysal O, Zeller W (2004) Extract of Hedera helix induces resistance on apple rootstock M26 similar to Acibenzolar-Smethyl against fire blight (Erwinia amylovora). Physiological and Molecular Plant Pathology 65:305-315.

Boro MC, Beriam LOS, Guzzo SD (2011) Induced resistance against Xanthomonas axonopodis pv. passiflorae in passion fruit plants. Tropical Plant Pathology 36:74-80.

Bradford MN (1976) A rapid and sensitive method for the quantitation of microgram quantities of protein utilizing the principle of protein-dye binding. Analytical Biochemistry 72:248254.

Brisset MN, Cesbron S, Thomson SV, Paulin JP(2000) AcibenzolarS-methyl induces the accumulation of defense-related enzymes in apple and protects from fire blight. European Journal of Plant Pathology 106:529-536.

Cavalcanti FR, Resende MLV, Pereira RB, Costa JCB, Carvalho CPS (2006) Atividades que quitinase e beta-1,3-glucanase após eliciação das defesas do tomateiro contra a mancha-bacteriana. Pesquisa Agropecuária Brasileira 41:1721-1730.

Cavalcanti FR, Resende MLV, Zacaroni AB, Ribeiro Júnior PM, Costa JCB, Souza RM (2006) Acibenzolar-S-metil e Ecolife na indução de respostas de defesa do tomateiro contra a mancha bacteriana (Xanthomonas vesicatoria). Fitopatologia Brasileira 31:372-380.

Chance B, Maehley AC (1955) Assay of catalases and peroxidases. Methods in Enzymology 2:764-775.

Conrath U, Pieterse CMJ, Mauch-Mani B (2002) Priming in plantpathogen interactions. Trends in Plant Science 7:210-216.

Conrath U (2011) Molecular aspects of defence priming. Trends in Plant Science 16:524-531.

Dubey NK, Shukla R, Kumar A, Singh P, Prakash B (2011) Natural Products in Plant Pest Management, Vol. 1. Wallingford, UK. CAB International.

Giordano LB, Boiteux LS, Quezado-Duval AM, Fonseca MEN, Resende FV, Reis A, González M, Nascimento WM, Mendonça JL (2010) 'BRS Tospodoro': a high lycopene processing tomato cultivar adapted to organic cropping systems and with multiple resistance to pathogens. Horticultura Brasileira 28:241-245.

Glazebrook J (2005) Contrasting mechanisms of defense against biotrophic and necrotrophic pathogens. Annual Review of Phytopathology 43:205-227.

Gonçalves RC, Alfenas AC, Mafia RG (2007) Armazenamento de microrganismos em cultura com ênfase a fungos fitopatogênicos. In: Alfenas AC, Mafia RG (Eds.) Métodos em Fitopatologia. Vol. 1. Viçosa, MG. Editora UFV. pp. 92-102.

Gurjar MS, Ali S, Akhtar M, Singh KS (2012) Efficacy of plant extracts in plant disease management. Agricultural Sciences $3: 425-433$ 
Ji P, Momol MT, Olson SM, Pradhanang PM, Jones JB (2005) Evaluation of thymol as biofumigant for control bacterial wilt of tomato under field conditions. Plant Disease 89:497-500.

Kado CI, Heskett MG (1970) Selective media for isolation of Agrobacterium, Corynebacterium, Erwinia, Pseudomonas and Xanthomonas. Phytopathology 60:969-976.

Kagale S, Marimuthu T, Thayumanavan B, Nandakumar R, Samiyappan R (2004) Antimicrobial activity and induction of systemic resistance in rice by leaf extract of Datura metel against Rhizoctonia solani and Xanthomonas oryzae pv. oryzae. Physiological and Molecular Plant Pathology 65:91-100.

Kar M, Mishra D (1976) Catalase, peroxidase and polyphenoloxidase activities during rice leaf senescence. Plant Physiology 57:315-319.

Lever M (1972) A new reaction for colorimetric determination of carbohydrates. Analytical Biochemistry 47:273-279.

Li L, Steffens JC (2002) Overexpression of polyphenol oxidase in transgenic tomato plants results in enhanced bacterial disease resistance. Planta 215:239-247.

Lopes CA, Santos JRM (1994) Doenças do Tomateiro. Brasília DF. Embrapa Hortaliças.

Louws FJ, Wilson M, Campbell HL, Cuppels DA, Jones JB, Shoemaker PB, Sahin F, Miller SA (2001) Field control of bacterial spot and bacterial speck of tomato using a plant activator. Plant Disease 85:481-488.

Mariconi FAM (1981) Inseticidas e seu Emprego no Combate às Pragas. Vol. 1. Defensivos. $5^{\text {a }}$ Ed. São Paulo, SP. Nobel.

Minami K, Haag HP (1989) O Tomateiro. 2ª Ed. Campinas, SP. Fundação Cargill.

Mueller WC, Beckman CH (1974) Ultra structure of the phenol storing cells in roots of banana. Physiological Plant Pathology 4:187-190.

Nicholson RL, Hammerschmidt R (1992) Phenolic compounds and their role in disease resistance. Annual Review of Phytopathology 30:369-389.

Osbourn A (1996) Saponins and plant defence - a soap story. Trends in Plant Science 1:4-9.

Pastor V, Luna E, Mauch-Mani B, Ton J, Flors V (2012) Primed plants do not forget. Environmental and Experimental Botany 94:46-56.

Quiroga M, Guerrero C, Botella MA, Barceló A, Amaya I, Medina MI, Alonso FJ, Forchetti MF, Tigier H, Valpuesta V (2000) A tomato peroxidase involved in the synthesis of lignin and suberin.
Plant Physiology 122:1119-1127.

Sangeetha G, Thangavelu R, Usha Rani S, Muthukumar A (2013) Antimicrobial activity of medicinal plants and induction of defense related compounds in banana fruits $\mathrm{cv}$. Robusta against crow rot pathogens. Biological Control 64:16-25.

Satya VK, Gayathiri S, Bhaskaran R, Paranidharan V, Velazhahan $\mathrm{R}$ (2007) Induction os systemic resistance to bacterial blight caused by Xanthomonas campestris pv. Malvacearum in cotton by leaf extract from medicinal plant zimmu (Allium sativum $\mathrm{L}$. $\mathrm{x}$ Allium cepa L.). Archives of Phytopathology and Plant Protection 40:309-322.

Scalbert A (1991) Antimicrobial properties of tannins. Phytochemistry 30:3875-3883.

Schaad NW (1988) Laboratory Guide for Identification of Plant Pathogenic Bacteria, ${ }^{\text {nd }}$ Ed. Saint Paul, MN, USA. APS Press.

Schneider RW, Grogan RG (1977) Bacterial speck of tomato: sources of inoculum and establishment of a resident population. Phytopathology 67:388-394.

Silva VL, Lopes CA (1995) Populações epifíticas de Pseudomonas syringae pv. tomato em cultivo comercial de tomateiro industrial. Fitopatologia Brasileira 20:179-183.

Soylu EM, Soylu S, Baysal O (2003) Induction of disease resistance and antioxidant enzymes by acibenzolar-S-methyl against bacterial canker (Clavibacter michiganensis subsp. michiganensis) in tomato. Journal of Plant Pathology 85:175-181.

Taiz I, Zeiger E (2004) Metabólitos secundários e defesa vegetal. In: Taiz I, Zeiger E (Eds.) Fisiologia Vegetal. $3^{\mathrm{a}}$. Ed. Porto Alegre, RS. Editora Artimed. pp. 309-332.

Van Loon LC (1997) Induced resistance in plants and the role of pathogenesis-related proteins. European Journal of Plant Pathology 103:753-765.

Van Loon LC, Rep M, Pieterse CMJ (2006) Significance of inducible defense-related proteins in infected plants. Annual Review of Phytopathology 44:135-162.

Wagner H, Bladt, S (1996) Plant Drug Analysis: A Thin Layer Chromatography Atlas. $2^{\text {nd }}$ Ed. New York, NY, USA. Springer.

Weller DM, Mavrodi DV, Van Pelt JA, Pieterse, CMJ, Van Loon LC, Bakker PAHM (2012) Induced systemic resistance in Arabidopsis thaliana against Pseudomonas syringae pv. tomato by 2,4-diacetylphloroglucinol-producing Pseudomonas fluorescens. Biological Control 102:403-412.

Zucher M (1965) Induction of phenylalanina deaminase by light and its relation to chlorogenic acid synthesis in potato tuber tissue. Plant Physiology 40:779-784. 